INTERNATIONAL JOURNAL OF

ARTIFICIAL INTELLIGENCE AND EMERGING

TECHNOLOGY

VOLUME 2, ISSUE 1, 2019, $1-3$.

www.egyptfuture.org/ojs/

\title{
DIORAMA PRESENTATION METHODS
}

\author{
Waad Adnan MAHMOUD *
}

Natural History Research Center and Museum, University of Baghdad, Iraq

\begin{abstract}
Diorama is the building of aesthetic scenes with functional purposes that take from the plastic techniques of sculpting, drawing and designing a field to carry out its reporting mission on a scientific topic as in natural circuits to dissect the brain or body functions or has aesthetic or decorative purposes such as scenes in cinemas or children's playing and the pleasure of participating in playing and creating amazement. Therefore, the researcher presented the research problem by asking the following question: What are the various methods of presentation in diorama? How do they affect the reception and response mechanisms, and how did diorama in nearby fields be used as a means of demonstration for medical, engineering, arts, urban construction and educational curricula? Then the researcher presented the conceptual framework, which is made up of two studies, the First Topic, Diorama, the Difference in Presentation and Themes, and the Second Topic, Diorama and the Multiplicity of Materials. The researcher presented in the conceptual framework the multiplicity and different methods of presentation and the investment of raw materials and the different fields of knowledge that entered diorama into its fields, which presented proposals and solutions in some cases for comprehension, understanding and abstract topics that cannot be seen, so they worked to represent them. In the third chapter, the researcher conducted three applied samples of different topics, methods of presentation, and goals (marshes, volcano, and beehives), as for in the fourth chapter, the researcher reached the results and conclusions, including the diversity of presentation methods in diorama according to the topic, purpose and the aesthetic and functional goals it carries through visual excitement transforming the art of diorama by representing it in different ways to perceive the transformation and reveal the aesthetics of the desert environment, mountains and forests, and to present various environments, then the researcher presented recommendations and suggestions, and then references and sources.
\end{abstract}

Keywords

Diorama, Presentation, Natural History, Museum, Iraq.

\section{Introduction}

Diorama is concerned with the representation of objects, assets and environments in a variety of different visual methods, using materials such as straw, wood, wires, environmental waste and leftover cartoons, and investing this in different techniques and methods of implementation and employing them in the models and dioramas in their variation from architectural to aesthetic diorama to historical, educational, excitement and interaction with scenes.

Using materials and techniques in implementing different roles and with various objectives, including aesthetic or educational, and presentation methods in diorama presuppose a shift in vision, perception and understanding of the subject visually, with the aim of communicating with the recipient, so that the act allows the transmission of information and its delivery to the mind in an effective visual speech.

\footnotetext{
*Corresponding author: info@nhm.uobaghdad.edu.iq
} 
Diorama is the construction of an aesthetic and functional event characterized by excitement and concerned with presenting a historical time period or an imaginary position, and engineering and environmental constructions in different and varied ways of display.

\section{Results}

1. Diorama is the construction of an aesthetic and functional scene that is characterized by visual excitement and is concerned with presenting a historical time period, a landscape, an imaginary situation, and engineering and environmental constructions.

2. Diorama collects techniques and creatively melts them, and in this way the diorama is formed in its diversity and innovation in employment and experimentation.

3. Diorama depends on the manufacture of three-dimensional models and various scenes and it is interested in studying the details of things to be presented to the viewer.

4. Diorama art provides an aesthetically pleasing visual document, whose purpose is to convey scenes in different spatial environments, and diorama is thus a wandering portable theatre and it is usually wrapped.

5. Diorama discusses the environment and represents it with different materials and techniques, and thus to remedy the transformation and reveal its aesthetics, as in diorama that represent cities, environments such as desert, forests, and marshes.

\section{Recommendations}

1. Using diorama in educational curricula because of its effect on interaction and creating an environment of fun and playing.

2. Employing diorama to develop the mind of students in schools which gives their imagination an act of innovation and creativity.

3. Benefiting from diorama in tourism projects, making models of the diverse environments of Iraq, archaeological areas, and religious shrines, and holding exhibitions thereof abroad as an attractive element for tourists.

\section{Suggestions}

The researcher proposes to conduct the following studies:

1. Methods of using diorama in educational curricula.

2. Using diorama in documenting the different environments of Iraq. 


\section{References}

1. Ahmad Husayn Abu Amira: Architecture, Planning and Urban Design - Part 1, First Edition, Arab Society Library for Publishing and Distribution, 2011.

2. Iyad Hussein Abdullah Al-Hussaini: The Technical Formation of Arabic Calligraphy According to the Basics of Design - University Theses Series, House of General Cultural Affairs, Iraq - Baghdad, i 1, 2008.

3. Basem Mustafa Al-Shamali: The Concept of Movement in the Art of Modern Sculpture - Journal of Damascus University for Engineering Sciences, Volume Twenty-Ninth, First Issue, 2017.

4. Jabbar Judi: Aesthetics of Scenography in the Theatrical Show, Publications of the Baghdad Festival for Arab Youth Theatre - Baghdad, Iraq 2012.

5. Rifaat Musa Muhammed: Introduction to Museum Art - the Egyptian Lebanese House.

6. Abbas Abd Mandil: Modern Museum Science - Dar Al-Saja for Printing and Publishing, First Edition, Iraq - Baghdad, 2019.

7. Georgiegachev: Awareness and Art - Translated by: Naufal Bayuf, The World of Knowledge, Kuwait.

8. Waad Adnan Mahmoud: Technical Diversity in the Scientific Model, Exhibition Halls in the Museum of Natural History, The Academic Magazine, Issue No. 26, 2017.

9. Waad Adnan Mahmoud: Aesthetics of Light in the Exhibition Hall, Journal of the Faculty of Basic Education, Volume 2, Issue 3, for the year 2016.

10. Waad Adnan Mahmoud: Environmental Art Practices in the Global Visual Scene, Journal of the Third Genetics and Environment Conference - Baghdad, 2015.

11. Waad Adnan: An interview with Al-Mutamar newspaper, No. (2921), 2014.

12. Waukaswonk: Book of the Principles of Sculpture Design, Translated by Amal AlHussein, Technical Institutes Foundation, Dar Al-Salam Press, Iraq - Baghdad, 1991.

13. https://en.wikipedia.org/wiki/Diorama

Received: January 25, 2019

Accepted: April 30, 2019 